\title{
Kualitas Air Sungai Dimembe Di Sekitar Pertambangan Emas Tanpa Izin Kecamatan Dimembe Kabupaten Minahasa Utara
}

\author{
Christian D. Makatipua*, Harry S. J. Koleangana, Audy Wuntua
}

aJurusan Kimia, FMIPA, Unsrat, Manado

\begin{tabular}{|c|c|}
\hline KATA KUNCI & A B S T R A K \\
\hline $\begin{array}{l}\text { Analisis, Pencemaran, } \\
\text { Kualitas Air, Sungai } \\
\text { Dimembe. }\end{array}$ & 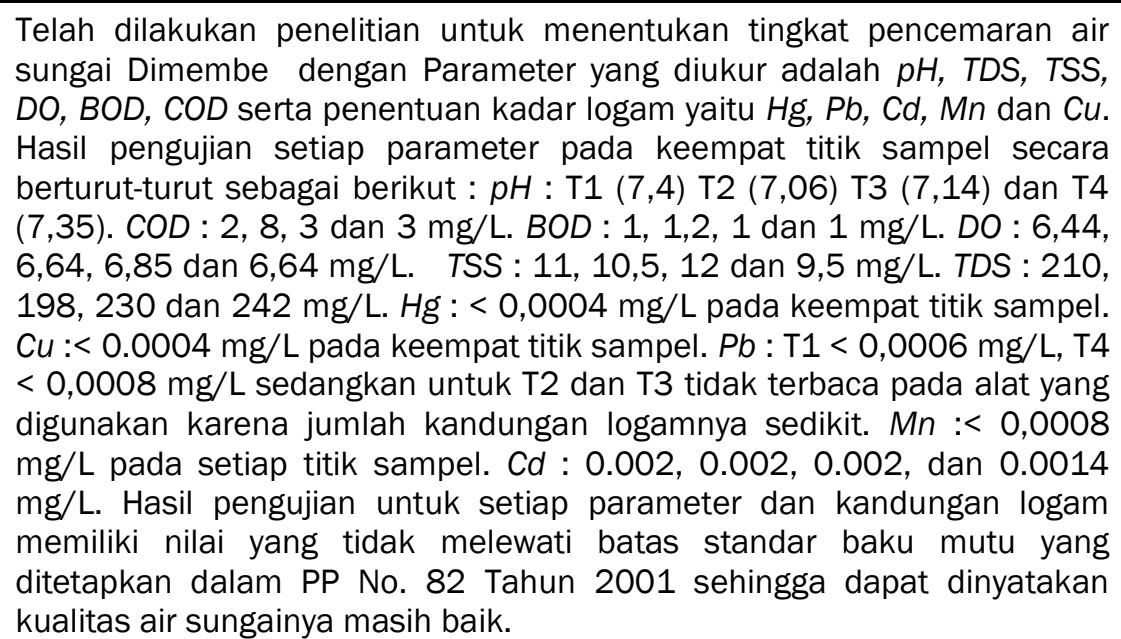 \\
\hline
\end{tabular}

K E Y W O R D S

Analysis, Pollution, Water

Quality, Dimembe River.

\begin{abstract}
A B S T R A C T
Research has been carried out to determine the level of contamination of Dimembe river water with the parameters measured are $\mathrm{pH}, \mathrm{TDS}, \mathrm{TSS}, \mathrm{DO}$, $\mathrm{BOD}, \mathrm{COD}$ and determination of metal content namely $\mathrm{Hg}, \mathrm{Pb}, \mathrm{Cd}, \mathrm{Mn}$ and $\mathrm{Cu}$. The test results for each parameter on the four sample points are respectively as follows: pH: T1 (7.4) T2 (7.06) T3 (7.14) and T4 (7.35). COD: 2, 8, 3 and $3 \mathrm{mg} /$ L. BOD: 1, 1,2, 1 and $1 \mathrm{mg} /$ L. DO: 6.44, 6.64, 6.85 and $6.64 \mathrm{mg} / \mathrm{L}$. TSS: 11, 10,5, 12 and $9.5 \mathrm{mg} / \mathrm{L}$. TDS: 210, 198, 230 and $242 \mathrm{mg} / \mathrm{L}$. $\mathrm{Hg}$ : <0,0004 mg / L on all four sample points. $\mathrm{Cu}$ : $<0,0004 \mathrm{mg} / \mathrm{L}$ on all four sample points. $\mathrm{Pb}$ : T1 <0,0006 mg / L, T4 $<0,0008 \mathrm{mg} / \mathrm{L}$ while for T2 and T3 it is not readable on the tool used because of the small amount of metal content. $\mathrm{Mn}:<0,0008 \mathrm{mg} / \mathrm{L}$ at each sample point. Cd: 0.002, 0.002, 0.002, and $0.0014 \mathrm{mg} / \mathrm{L}$. The test results for each parameter and metal content have values that do not exceed the limits of the quality standard set in PP No. 82 of 2001 so that the river water quality can be stated is still good.
\end{abstract}

TERSEDIA ONLINE

01 Agustus 2019

1. Pendahuluan

Air permukaan seperti sungai banyak dimanfaatkan untuk keperluan manusia seperti tempat penampungan air, alat transportasi, mengairi sawah dan keperluan peternakan, keperluan industri perumahan, sebagai daerah tangkapan air, pengendalian banjir, ketersediaan air, dan irigasi (Yuliastuti, 2011).Adanya peningkatan kegiatan pembangunan di berbagai bidang secara langsung mempunyai dampak terhadap kerusakan lingkungan termasuk didalamnya pencemaran sungai yang berasal dari limbah domestik maupun non domestik.Oleh karena

*Corresponding author: Jurusan Kimia FMIPA UNSRAT, Jl. Kampus Unsrat, Manado, Indonesia 95115; Email address: davemak02@gmail.com 
itu pencemaran air sungai dan lingkungan sekitarnya perlu dikendalikan seiring dengan laju pembangunan agar fungsi sungai dapat dipertahankan kelestariannya (Yudo, 2006).

Kegiatan penambangan emas yang dilakukan oleh masyarakat yang ada di wilayah Kecamatan Dimembe Kabupaten Minahasa Utara telah berlangsung sejak tahun 1985 sampai sekarang.Kegiatan penambangan ini dilakukan secara tradisional. Proses pengolahannya hanya menggunakan peralatan yang sangat sederhana. Proses pengolahan emas ini dilakukan dengan mengikuti beberapa tahapan antara lain penggalian batuan, pengolahan, dan pembuangan limbah. Setiap tahapan proses ini secara ekologi membawa dampak yang dapat mengganggu keseimbangan lingkungan (Sumual, 2009).

Senyawa atau zat-zat yang berbahaya yang masuk ke dalam air yang dapat mencemari air dinamai polutan.Polutan pada umumnya mempunyai sifat racun atau toksik yang berbahaya bagi organisme hidup.Toksisitas atau daya racun dari polutan itulah yang menjadi pemicu terjadinya pencemaran (Bana et al., 2015).Beberapa limbah yang dibuang ke perairan adakalanya berupa limbah B3 (Bahan Beracun Berbahaya), limbah B3 ini mengandung logam berat yang apabila masuk ke ekosistem dapat menimbulkan dampak yang fatal, baik bagi biota perairan maupun manusia yang ada di wilayah tersebut (Sari, 2017).

Limbah pembuangan tersebut dapat mengganggu kualitas air sungai yang dapat dilihat berdasarkan sifat-sifat fisika dan kimia air yaitu perubahan kualitas pada pH, BOD, COD, DO,TDS, dan TSS (Gani, 2017). Dampak dari pembuangan limbah pada air penerima dapat dilihat dari oxygen demand (DO).Dua parameter yang paling umum digunakan untuk mengenali komposisi air limbah adalah biochemical oxygen demand (BOD) dan chemical oxygen demand (COD) (Abdallah et al., 2014). Pengukuran kandungan total logam tidak memberikan informasi yang tetap tentang tingkat resiko lingkungan, karena tidak semua bentuk kimia dari logam tertentu memiliki dampak lingkungan yang sama. Dengan demikian, analisis fraksi logam sangat penting untuk karakterisasi sampel lingkungan karena memberikan informasi tentang mobilitas logam dan ketersediaan logam (Alvarez et al., 2012).

Metode yang digunakan adalah spektroskopi serapan atom (SSA) secara luas digunakan untuk memberikan teknik yang sensitif dan selektif dalam analisis senyawa anorganik (Skinner et al., 2007).Spektroskopi serapan atom (SSA) pada dasarnya merupakan teknik yang sangat sederhana.Pada panjang gelombang resonansi suatu unsur, cahaya dapat diserap oleh atom-atom unsur tersebut dalam fase uap.Sinyal SSA merupakan pengurangan cahaya dari sumbernya yang secara monotonik berkorelasi dengan jumlah atom yang dilewatinya (Slavin et al., 2008). Berdasarkan uraian di atas, untuk memberikan informasi tentang kualitas air sungai yang ada di Kab. Minahasa Utara perlu dilakukan penelitian tentang sifat kimia dan fisika pada air sungai Dimembe Kec. Dimembe Kab. Minahasa Utara, dengan pengujian $\mathrm{pH}$, Biochemical Oxygen Demand (BOD), Chemical Oxygen Demand (COD), Dissolved Oxygen (DO), Penentuan kadar logam, Total Suspended Solid (TSS) dan Total Dissolved Solid (TDS).

Tujuan dari penelitian ini adalah untuk Menganalisis sifat-sifat fisika dan kimia air sebagai akibat Penambangan Emas Tanpa Izin (PETI) di sungai Dimembe dan mengidentifikasi kehadiran dan distribusi logam-logam berat yang terkandung di dalam air sungai Dimembe.Material dan Metode

\section{Material dan Metode}

Penelitian ini dilakukan di Laboratorium Baristand Industri Manado, pada bulan Mei-Juni 2018.Sampel air diambil dari sungai yang berada disungai Dimembe, Kecamatan Dimembe, Kabupaten Minahasa Utara dengan empat titik pengambilan. Titik pertama (T1) terletak $10 \mathrm{~m}$ sebelum lokasi penambangan liar, titik kedua (T2) lokasi penambangan liar, (T3) titik ketiga $10 \mathrm{~m}$ setelah lokasi penambangan liar, dan titik keempat (T4) terletak berjarak $100 \mathrm{~m}$ setelah lokasi penambangan liar ke arah pemukiman warga.

Bahan-bahan yang digunakan dalam penelitian ini adalah sampel air sungai, aquades, larutan asam sulfanilat, larutan naftil etilendiamin dihidroklorida, larutan asam klorida $1 \mathrm{M}$, larutan fenol, larutan natrium nitro prusida, larutan mangan sulfat, larutan alkaliiodida azida, asam sulfat pekat, larutan natrium tiosulfat $0,025 \mathrm{M}$, larutan kalium permanganate $0,033 \mathrm{M}$, larutan asam oksalat 0,05 $\mathrm{M}$, asam sulfat $0,01 \mathrm{M}$.

Instrumen yang digunakan dalam penelitian ini Atomic Absorption Spectrophotometer (SSA) (AA7000 Shimadzu), dan spektrofotometer serapan atom uap dingin atau Mercury Analyzer dengan perlengkapannya.

Sampel yang akan digunakan merupakan air sungai pada sekitaran penambangan emas tanpa izin (PETI) diambil pada 4 titik berbeda. Sampel ditampung dalam 4 botol polietilen dengan volume $2 \mathrm{~L}$, dismpan pada kotak pendingin berisikan es. Titik pertama (T1) terletak pada $10 \mathrm{~m}$ sebelum lokasi penambangan, titik kedua (T2) terletak berdekatan dengan lokasi penambangan, titik ke tiga (T3) terletak pada $10 \mathrm{~m}$ setelah lokasi penambangan, dan titik ke yang terakhit (T4) terletak pada $100 \mathrm{~m}$ setelah lokasi penambangan. 


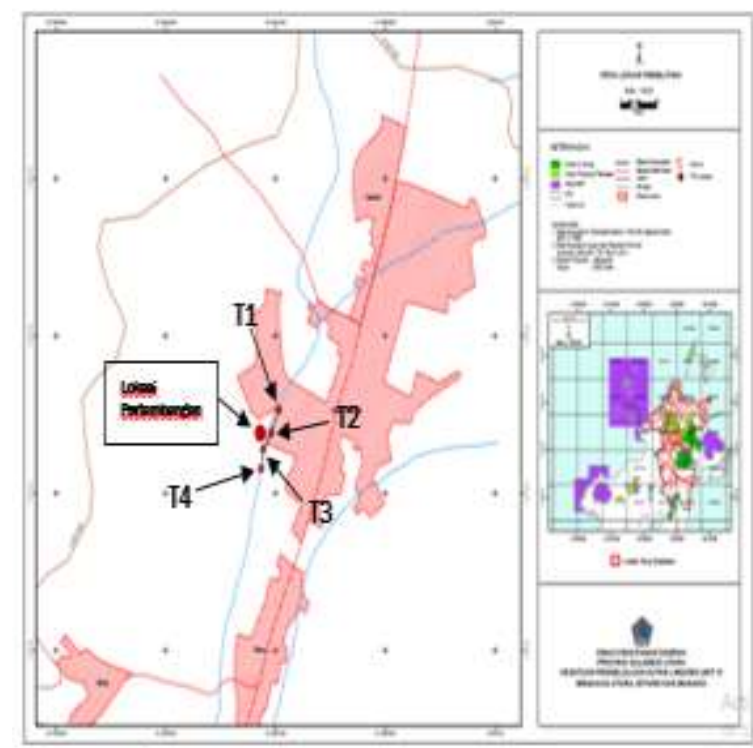

Prosedur Kerja

Analisis parameter kualitas air dikerjakan mengikuti prosedur SNI yaitu:

1. SNI 01-3554-2006 Untuk penentuan $\mathrm{pH}$

2. SNI 06-6989. 27-2005 Untuk penentuan total padatan terlarut

3. SNI 06-6989.3-2004 Untuk penentuan total padatan tersuspensi

4. Sni 06-6989.14-2004. Untuk penentuan oksigen terlarut

5. Sni 06-6989.14-2004. Untul penentuan kebutuhan oksigen biokimia

6. Sni 06-6989.14-2004. Untuk penentuan kebutuhan oksigen kimia

7. Sni 6989.78-2011 Untuk cara uji merkuri (Hg) secara spektrofotometri serapan atom (ssa)nyala

8. Sni 6989.8-2009Untuk cara uji timbal (Pb) secara spektrofotometri serapan atom (ssa)nyala

9. Sni 6989.16-2009Untuk cara uji kadmium (Cd) secara spektrofotometri serapan atom (ssa)nyala

10. Sni 6989.5-2009Untuk cara uji mangan (Mn) secara spektrofotometri serapan atom (ssa)nyala

11. Sni 6989.6-2009Untuk cara uji tembaga (Cu) secara spektrofotometri serapan atom (ssa)nyala

\section{Hasil dan Pembahasan}

Hasil pengukuran untuk parameter-parameter $\mathrm{pH}$, COD, BOD, DO, TDS, TSS, dan logam-logam merkuri $(\mathrm{Hg})$, tembaga $(\mathrm{Cu})$, timbal $(\mathrm{Pb})$, mangan $(\mathrm{Mn})$, dan cadmium (Cd) ditunjukkan pada Tabel 1.

\begin{tabular}{|c|c|c|c|c|c|c|c|}
\hline \multirow[t]{2}{*}{ lo } & \multirow[t]{2}{*}{ Paraneter } & \multicolumn{4}{|c|}{ Hasi/Analsis } & \multirow[t]{2}{*}{ BM } & \multirow[t]{2}{*}{ Satua: } \\
\hline & & 71 & 72 & $T 3$ & $T 4$ & & \\
\hline 1 & PH & 7,40 & 7,66 & 7,14 & 7,35 & 69 & - \\
\hline 2 & 000 & 2 & 8 & 3 & 3 & 10 & $\mathrm{mg} / \mathrm{L}$ \\
\hline 3 & 800 & 1 & 12 & 1 & 1 & 2 & $\mathrm{me} / \mathrm{L}$ \\
\hline 4 & $\infty 0$ & 6,44 & 664 & 6,85 & 6,64 & 6 & mgll \\
\hline 5 & TSS & 11 & 105 & 12 & 9.5 & 50 & $\mathrm{mg}$ - \\
\hline 6 & $\mathrm{TC6}$ & 210 & 198 & 230 & 242 & 1000 & $\mathrm{mgl}$ \\
\hline 7 & $\mathrm{Hg}$ & 0,0004 & 60,0004 & $<0,0004$ & $<0,0004$ & 0,001 & $\mathrm{mg} / \mathrm{L}$ \\
\hline 8 & $a$ & 000004 & 00,0004 & $<0,0004$ & $\$ 0,0004$ & 0,02 & $\mathrm{mg} \mathrm{g}$ \\
\hline 9 & $P_{2}$ & 0,0606 & 80,0004 & $<0,0004$ & 0,0008 & 0,03 & $\operatorname{mgl} \mathrm{L}$ \\
\hline 10 & 算 & 0,0008 & 00,0008 & $<0,0008$ & 40,0008 & 1 & $\mathrm{mg} / \mathrm{L}$ \\
\hline 11 & $\mathrm{Cd}$ & 0,002 & 0,002 & 0,002 & 0,0011 & 001 & $\mathrm{mg} / \mathrm{L}$ \\
\hline
\end{tabular}

Hasil pengukuran $\mathrm{pH}$ pada 4 titik pengambilan sampel di sungai dimembe yang dialiri penambangan rakyat mempunyai kisaran nilai yang bervariasi. Berdasarkan Peraturan Pemerintah No. 82 Tahun 2001 tentang pengolahan kualitas air dan pengendalian pencemaran air menetapkan nilai baku mutu air berada pada kisaran pH 6-9. Beradasarkan hasil penelitian yang dilakukan pada empat titik pengambilan sampel menunjukan penurunan $\mathrm{pH}$ dari titik T1 ke T3 dengan nilai T1 sebesar 7,4, T2 7,06 dan T3 sebesar 7,14. Selanjutnya terjadi kenaikan $\mathrm{pH}$ kembali pada T4 sebesar 7.35 dengan nilai yang tidak berbeda jauh dengan nilai pH pada T1. Walaupun tidak melewati standar baku mutu akan tetapi dapat dilihat bahwa limbah berpengaruh terhadap air sungai, yaitu menyebabkan penurunan $\mathrm{pH}$ pada aliran Sungai Dimembe Kecamatan Dimembe Kabupaten Minahasa Utara, Fluktuasi nilai pH dipengaruhi oleh adanya buangan limbah organik dan anorganik ke sungai.

Chemical oxygen demand (COD) adalah jumlah oksigen yang diperlukan untuk mengurai seluruh bahan organik yang terkandung dalam air (Agustira et al., 2013). Angka COD merupakan ukuran bagi pencemaran air oleh zat organik yang secara alamiah dapat dioksidasi melalui proses mikrobiologis dan mengakibatkan berkurangnya oksigen terlarut dalam air. Beradasarkan hasil penelitian yang dilakukan, nilai COD terbesar berada pada T2 sebesar $8 \mathrm{mg} / \mathrm{L}$. Dalam PP No. 82 Tahun 2001 nilai maksimum COD yang diperbolehkan adalah $10 \mathrm{mg} / \mathrm{L}$. Semua nilai pada titik pengambilan contoh uji semuanya berada tidak melewati batas standar baku mutu. Akan tetapi terjadi perubahan yang cukup besar pada T2 yang berada pada aliran sungai yang mengaliri penambangan. Peningkatan nilai COD ini disebabkan oleh buangan limbah cair yang bersumber dari penambangan, di mana limbah cair yang merupakan hasil pengolahan yang dibuang mengandung beberapa unsur organik dan anorganik, seperti yang dikemukakan Abdallah, et al. (2014), bahwa limbah cair mengandung 99,9\% bahan cair dan $0,1 \%$ bahan padatan yang terdiri dari unsur organik dan anorganik. Jumlah daripada 
unsur organik dan anorganik inilah yang mempengaruhi kenaikan niai COD tersebut (Agustira, et al. 2005).Walaupun begitu air sungai masih belum tercemar dikarenakan pengolahan limbah penambangan yang dikelola dengan baik.

Biochemical oxygen demand (BOD) adalah suatu karakteristik yang menunjukan jumlah oxygen terlarut yang diperlukan oleh mikroorganisme (bakteri) untuk mengurai bahan organik dalam kondisi aerobik (Agustira et al., 2013).Makin besar konsentrasi BOD suatu perairan, menunjukkan konsentrasi bahan organik di dalam air makin tinggi (Yudo et al., 2010). Beradasarkan hasil penelitian dapat dilihat bahwa, semua titik tidak melewati batas standar baku mutu air yang ditetapkan berdasarkan PP No. 82 Tahun 2001 tentang pengolahan kualitas air dan pengendalian pencemaran air. Walaupun ke empat titik tersebut tidak ada yang melewati batas standar baku mutu akan tetapi terdapat kenaikan kadar BOD pada T2, yaitu aliran yang berada tepat di dekat penambangan dengan nilai sebesar $1.2 \mathrm{mg} / \mathrm{L}$ dan kembali stabil pada T3, yaitu aliran sungai yang berjarak $10 \mathrm{~m}$ setelah lokasi penambangan. Hal ini disebabkan karena adanya kandungan limbah organik yang dihasilkan dari pembuangan limbah sisa penambangan. Seluruh titik tersebut memiiki kadar BOD yang memenuhi standar baku mutu air yang ditetapkan PP No. 82 Tahun 2001 yaitu 2 $\mathrm{mg} / \mathrm{L}$. Hal ini menunjukan bahwa perairan tersebut tidak tercemar dan layak untuk digunakan oleh masyarakat sekitar.

Parameter oksigen terlarut (DO) digunakan sebagai indikator tingkat kesegaran air. Oksigen penting sebagai indikator kualitas perairan, karena oksigen terlarut berperan penting dalam proses oksidasi dan reduksi bahan organik dan anorganik. Karena proses oksidasi dan reduksi inilah maka peran DO sangat penting untuk membantu mengurangi beban pencemaran pada perairan secara alami (Sari. 2017). Beradasarkan hasil penelitian, pengukuran DO pada empat titik memiliki rentang nilai $6,44 \mathrm{mg} / \mathrm{L}$ sampai $6,85 \mathrm{mg} / \mathrm{L}$ dengan nilai DO terendah berada pada T1 dengan nilai $6,44 \mathrm{mg} / \mathrm{L}$ kemudian naik hingga T3 dengan nilai $6.85 \mathrm{mg} / \mathrm{L}$ dan kemudian kembali mengalami penurunan pada T4 dengan nilai $6.64 \mathrm{mg} / \mathrm{L}$. Keseluruhan Nilai yang didapat berdasarkan hasil penelitian memenuhi standar baku mutu untuk DO yaitu 6 mg/L berdasarkan PP No. 82 Tahun 2001. Penurunan kadar DO ini disebabkan oleh pembuangan limbah yang berasal dari pasar yang berada di dekat aliran sungai. Rendahnya nilai oksigen terlarut dalam air akan berdampak buruk bagi kehidupan biota yang ada di dalam perariran tersebut. Berdasarkan penelitian yang dilakukan Wardhana, 2004 dalam Ali et al. (2013) menyatakan bahwa air yang telah tercemar menyebabkan kandungan oksigen sangat rendah, di mana makin banyak bahan buangan organik di dalam air makin sedikit sisa kandungan oksigen yang terlarut di dalam air. Hal ini menandakan bahwa kualitas air sungai Dimembe untuk parameter DO masih dalam kondisi baik.

Beradasarkan hasil penelitian, pengujian parameter TSS pada ke empat titik pengambilan sampel, terlihat bahwa, pada T2 diperoleh nilai tertinggi sebesar $12 \mathrm{mg} / \mathrm{L}$, sedangkan pada titik-titik yang lainnya, secara berurutan T1, T2, dan T4 adalah $11 \mathrm{mg} / \mathrm{L}, 10,5 \mathrm{mg} / \mathrm{L}$ dan 9,5 mg/L. Secara keseluruhan, semua ini masih berada pada standar baku mutu berdasarkan PP No. 82 Tahun 2001 yaitu dibawah 200 mg/L. Menurut Sepriani. (2016), hal ini menunjukan bahwa limbah yang dibuang ke aliran air sungai tidak mengandung padatan yang dapat mempengaruhi kualitas air sungai tersebut.

Total Dissolved Solid (TDS) adalah ukuran zat terlarut (baik itu zat organik maupun anorganik, misalnya garam dan sebagainya) yang terdapat dalam sebuah larutan. TDS meter menggambarkan jumlah zat terlarut dalam part per million (ppm) atau sama dengan miligram per liter (Agustira et al., 2013). Perubahan konsentrasi TDS dapatberbahaya karena kepadatan air menentukan aliran air masuk dan keluar dari sel-sel organisme. Nilai konsentrasi TDS yang tinggi akan mengurangi kejernihan air dan berakibat buruk pada tanaman air untuk melakukan fotosintesis. Nilai total TDS Beradasarkan hasil penelitian ini sangat rendah yaitu secara berurutan dari T1 sampai T4 secara berurutan bernilai 210; 198; 230; 242, serta tidak melewati batas baku mutu, yaitu $1000 \mathrm{mg} / \mathrm{L}$. Walaupun tidak melewati batas baku mutu namun ada perubahan nilai yang terjadi pada setiap titik, yang menandakan bahwa padatan yang masuk ke sungai lebih banyak yang berbentuk padatan ukuran kecil (padatan terlarut) atau lebih didominasi oleh padatan yang berasal dari pembuangan limbah sekitar air sungai.

Pada hasil analisis merkuri, diperoleh kadar logam merkuri yang telah melewati batas nilai limited Detection pada pembacaan alat Spektrofotometer Serapan Atom dengan nilai < 0,0004 mg/L pada tiap titik (T1,T2, T3, dan T4), sehingga kadar merkuri yang diperoleh tidak melebihi standart baku mutu pada PP No. 82 Tahun 2001 tentang pengolahan kualitas air dan pengendalian pencemaran air yaitu sebesar 0,001 mg/L. Menurut Gani, (2017). Hal ini dikarenakan pada penambangan ini tidak menggunakan merkuri pada proses amalgamasi, tetapi yang digunakan adalah sianida, proses sianidasi pada Penambangan Emas Tanpa Izin. Peneliti menguji logam merkuri dikarenakan logam tersebut terdapat dalam salah satu parameter yang harus diuji sesuai PP No. 82 Tahun 2001 tentang pengolahan kualitas air dan pengendalian pencemaran air.Merkuri merupakan zat yang sangat beracun bagi makhluk hidup baik sebagai unsur tunggal maupun yang telah membentuk persenyawaan (Sumual, 2009).Keracunan oleh merkuri nonorganik terutama 
mengakibatkan terganggunya fungsi ginjal dan hati. Disamping itu akan mengganggu sistem enzim dan mekanisma sintetik apabila berupa ikatan dengan kelompok sulfur di dalam protein dan enzim, kemudian untuk merkuri organik dari jenis metilmerkuri dapat memasuki placenta dan merusak janin pada wanita hamil, mengganggu saluran darah ke otak serta menyebabkan kerusakan otak (Herman, 2006).

Beradasarkan hasil penelitian logam tembaga, pembacaan pada T1, T2, T3, dan T4 pada Spektrofotometer Serapan Atom melewati batas nilai Limited Detection yaitu dengan nilai < 0.0004 $\mathrm{mg} / \mathrm{L}$. Hal ini kemungkinan logam tembaga nilainya terbilang rendah sehingga tidak dapat dicantumkan nilai logam tembaga pada alat. Berdasarkan PP No. 82 Tahun 2001 tentang pengolahan kualitas air dan pengendalian pencemaran air, jumlah standar tembaga adalah senilai $0.02 \mathrm{mg} / \mathrm{L}$, dan berdasarkan hasil analisis untuk setiap titik pada aliran sungai, dapat disimpulkan bahwa kandungan tembaga tidak melewati batas dan terbilang tidak tercemar. Menurut Gani, et al. (2017), tembaga termasuk dalam logam esensial, dan dalam kadar yang rendah dibutuhkan oleh organisme sebagai koenzim dalam proses metabolisme tubuh dan sifat racunnya baru muncul dalam kadar yang tinggi.

Kadar timbal pada penelitian yang telah dilakukan menunjukan bahwa air limbah Penambangan Emas Tanpa Izin desa Dimembe pada T1 dan T4 mengandung logam timbal yang terbaca pada alat Spektrofotometer Serapan Atom dan tidak melewati batas nilai Limited Detection, dengan nilai $\mathrm{T} 1=0,0006 \mathrm{mg} / \mathrm{L}$ dan $\mathrm{T} 4=0,0008$ mg/L. Sedangkan untuk T2 dan T3 tidak dapat terbaca oleh alat Spektrofotometer Serapan Atom dikarenakan melewati batas nilai Limited Detection yaitu <0,0004 mg/L, itu dikarenakan jumlah kandungan logam timbal yang sedikit dan melewati batas nilai Limited Detection sehingga tidak terbaca. Titik-titik yang diambil dari sungai Dimembe tersebut dapat dilihat pada Tabel 10. mengandung kadar logam timbal yang sedikit sehingga nilai kadar timbal tersebut belum mencemari dan melewati batas baku mutu tentang kualitas air sungai berdasarkan PP No 82 Tahun 2001 yaitu 0,03 $\mathrm{mg} / \mathrm{L}$. adanya konsentrasi $\mathrm{Pb}$ pada Titik pengambilan sampel dikarenakan, $\mathrm{Pb}$ di dalam tanah mempunyai kecenderungan terikat oleh bahan organik dan sering terkonsentrasi pada bagian atas tanah karena menyatu dengan tumbuhan, dan kemudian terakumulasi sebagai hasil pelapukan di dalam lapisan humus (Herman, 2006). Jika kadar timbal tinggi, logam ini dapat bersifat racun dan mengakibatkan anemia, sakit ginjal, kerusakan sistem saraf serta merusak kehidupan binatang. Logam ini berada dalam darah dapat bereaksi dengan reaktif terhadap oksigen dan membentuk senyawa $\mathrm{PbO}$ yang sangat tidak dibutuhkan oleh hemoglobin darah (Yuliastuti. 2011).
Mangan merupakan nutrisi yang esensial bagi tumbuhan dan hewan (Effendi, 2003). Tumbuhan yang membusuk dan bangkai hewan menyumbangkan secara nyata sedikit logam ke atas air permukaan dan dasar endapan. Kegiatan manusia juga merupakan suatu sumber utama pemasukan logam ke dalam lingkungan perairan.Hasil dari pengujian sampel dengan parameter mangan menunjukan bahwa sampel yang diambil memiliki konsentrasi yang kecil, dan melewati batas Limited Detection pada alat Spektrofotometer Serapan Atom. Konsentrasi dari pada masing titik adalah $<0,0008$. Hasil yang begitu kecil menunjukan bahwa logam berat mangan tidak mempengaruhi aliran air sungai Dimembe. Berdasarkan hasil analisa, konsentrasi $\mathrm{Mn}$ sangat kecil dan tidak melewati standar baku mutu berdasarkan PP No 82 Tahun 2001 yaitu 1 mg/L.

Kadmium bersifat racun dan merugikan bagi semua organisme hidup bahkan juga berbahaya bagi manusia.Tidak jarang kadmium dijumpai dalam air karena adanya resapan dari tempat pembuangan limbah bahan kimia.Beberapa efek yang ditimbukan akibat pencemaran kadmium adalah adanya kerusakan ginjal, liver, sistem imun, sistem saraf dan darah (Sepriani, et al. 2010). Berdasarkan hasil pengujian sampel air sungai, dapat dilihat pada tabel bahwa kadar nilai kadmium memiliki nilai yang baik yaitu secara berurutan $\mathrm{T} 1=$ 0,002; T2 = 0,002; T3 =0,002; dan T4 =0,0014 dan tidak melampaui batas nilai baku mutu yang telah ditetapkan baku mutu air sungai berdasarkan PP No 82 Tahun 2001 yaitu 0,01 mg/L. Pada T1 sampai T3 memiliki nilai yang sama dan terjadi penurunan konsentrasi pada T4. Kadar keempat titik ini belum berbahaya bagi kehidupan biota perairan sungai dan masyrakat sekitar.

\section{Kesimpulan}

Penelitian yang dilakukan menunjukan bahwa hasil pengujian sample air sungai Dimembe untuk parameter BOD, COD, DO, TDS, TSS, Merkuri, Tembaga, Timbal, Mangan, dan Kadmium tidak melewati batas bakumutu yang ditetapkan PP No. 82 Tahun 2001.

\section{Daftar Pustaka}

Abdallah.M., Kennedy. K., Roberto. N., dan Warith. M. 2014. A New Computational Control Strategy For Leachate Management In Bioreactor Landfills. Enviromental Technology. 35(3) : 300312.

Agustira. R., Kemala, S.L. dan Jamilah. 2013. Kajian Karakteristik Kimia Air, Fisika Air dan Debit Sungai pada Kawasan DAS Padang Akibat Pembuangan Limbah Tapioka. Jurnal Agroekoteknologi. 1: 615-625.

Alvarez. M.A., dan Carrillo. G. 2012. Simultanes Determination Of Arsenic, Cadmium, Copper, Chromium, Nickel, Lead And Thallium In Total Disgested Sediment Samples And Avaible Fractions By Electhermal Atomization Atomic Absorption Spectrscopy (ET AAS). Talanta. 97(2012) : 505-512. 
Badan Standardisasi Nasional. 2004. SNI 066989.14-2004. Cara Uji Oksigen Terlarut (Modifikasi Azida). Jakarta.

Badan Standardisasi Nasional. 2004. SNI 066989.3-2004. Cara Uji Total Suspensi Solid. Jakarta.

Badan Standardisasi Nasional. 2005. SNI 06-6989. 27-2005. Cara Uji Total Disolved Solid. Jakarta.

Badan Standardisasi Nasional. 2009. SNI 6989.162009. Cara Uji Kadmium (Cd) Secara Spektrofotometri Serapan Atom (SSA)-nyala. Jakarta.

Badan Standardisasi Nasional. 2009. SNI 6989.52009. Cara Uji Mangan (Mn) Secara Spektrofotometri Serapan Atom (SSA)-nyala. Jakarta.

Badan Standardisasi Nasional. 2009. SNI 6989.62009. Cara Uji Tembaga (Cu) Secara Spektrofotometri Serapan Atom (SSA)-nyala. Jakarta.

Badan Standardisasi Nasional. 2009. SNI 6989.722009. Cara Uji Biochemical Oxigen Demand. Jakarta.

Badan Standardisasi Nasional. 2009. SNI 6989.82009. Cara Uji Timbal (Pb) Secara Spektrofotometri Serapan Atom (SSA)-nyala. Jakarta.

Badan Standardisasi Nasional. 2011. SNI 6989.782011. Cara Uji Raksa (Hg) Secara Spektrofotometri Serapan Atom (SSA)-uap Dingin atau Mercury Analyzer. Jakarta.

Badan Standardisasi Nasional.2006. SNI 01-35542006. Cara Uji pH. Jakarta.

Bana. V.S.S., Yulianti. L.I.M., dan Pranata.F.S. 2015. Potensi Pektin Kulit Pisang Kepok (Musa paradisiaca forma typical) Untuk Menyerap Logam Berat Kadmium (Cd). Jurnal Kimia. 1(1) : 1-7.

Effendi. H. 2003. Telaah Kualitas Air Bagi Pengelolaan Sumber Daya dan Lingkungan Perairan. KANISIUS, Yogyakarta.

Gani. R.P., Abidjullu. J., dan Wuntu.D.A. 2017.Analisis Air Limbah Pertambangan Emas Tanpa Izin Desa Bakan Kecamatan Lolayan Kabupaten Bolaang Mongondow.Jurnal MIPA Unsrat Online. 6(2) : 6-11.

Herman. Z.D. 2006. Tinjauan Terhadap Tailing Mengandung Unsur Pencemar Arsen (As), Merkuri (Hg), Timbal (Pb), dan Kadmium (Cd) dari Sisa Pengolahan Bijih Logam. Jurnal geologi indonesia. 1(1) : 31-36.

Sari. A. 2017. Kajian Kandungan Logam Berat Timbal (Pb), Kadmium (Cd), Tembaga ( $\mathrm{Cu}$ ) Kromium ( $\mathrm{Cr}$ ) dan Mangan (Mn) Pada Ikan Teri Kering (Stolephorus sp.) di Pesisir Teluk Lampung Secara Spektrofotometri Serapan Atom [Skripsi]. FMIPA Unila, Bandar Lampung.

Sepriani., Abidjullu. J., dan Koleangan.J.S.H. 2016.Pengaruh Limbah Cair Industri Tahu Terhadap Kualitas Air Sungai Paal 4 Kecamatan
Tikala Kota Manado.Chemical Progres. 9(1) : 35-40.

Skinner. K., Wright. N., and Porter-Goff. E. 2007. Mercury Uptake And Accumulation By Four Species Of Aquatic Plants. Enviromental Pollution. 145(2007) : 234-237.

Slavin.W., Carnick. G. C., and Koirtyohann. R. 2008. Background Corrections In Atomic Absorption Spectroscopy (AAS). C R C Critical Reviews in Analytical Chemistry. 19(2) : 95-134.

Sumual. H. 2009. Karakterisasi Limbah Tambang Emas Rakyat Dimembe Kabupaten Minahasa Utara. Jurnal Agritek. 17(5) : 258-270.

Yudo. S. 2006. Kondisi Pencemaran Logam Berat Diperairan Sungai DKI Jakarta.Jurnal Akuntasi dan Investasi. 2(1) : 1-15.

Yuliastuti. E. 2011. Kajian Kualitas Air Sungai Ngringo Karanganyar Dalam Upaya Pengedaian Pencemaran Air [Tesis]. MIL UNDIP, Semarang 